\title{
PENGARUH MODEL PEMBELAJARAN INKUIRI TERHADAP KEMAMPUAN MENULIS TEKS ANEKDOT OLEH SISWA KELAS X SMA SWASTA SWADAYA BULU CINA KECAMATAN HAMPARAN PERAK
}

\author{
Nurli Syahputri, Prina Yelli, Dewi Rulia Br Sitepu \\ ${ }^{1}$ Mahasiswa STKIP Budidaya Binjai \\ Isyahputrynurly@gmail.com \\ ${ }^{2,3}$ Dosen STKIP Budidaya Binjai \\ 2 prinayelly4@mail.com \\ 3 dewiruliasitepu@gmail.com
}

\begin{abstract}
ABSTRAK
Penelitian ini bertujuan untuk mengetahui pengaruh model pembelajaran inkuiri terhadap kemampuan menulis teks anekdot oleh siswa kelas X SMA Swasta Swadaya Bulu Cina Kecamatan Hamparan Perak. Sampel yang digunakan sebanyak 25 orang siswa. Jenis penelitian ini merupakan penelitian kuantitatif dengan metode quasi eksperimen. Desain penelitian dalam penelitian ini adalah one group pre test-post test design. Instrumen yang digunakan untuk mengumpulkan data dalam penelitian ini adalah tes. Teknik pengumpulan data yang digunakan adalah observasi dan dokumentasi. Teknik analisis data menggunakan teknik komputerisasi SPSS untuk dapat melakukan penarikan kesimpulan Berdasarkan hasil analisis data dapat disimpulkan bahwa nilai rata-rata kemampuan menulis teks anekdot siswa sebelum diterapkannya model pembelajaran inkuiri hanya sebesar 59,76 dan setelah diterapkannya model pembelajaran inkuiri menjadi 71,12. Nilai $t_{\text {hitung }}$ lebih besar dari nilai $t_{\text {tabel }}$ yaitu 2,25 lenih besar dari 2,05 yang artinya terdapat pengaruh model pembelajaran inkuiri terhadap kemampuan menulis teks anekdot oleh siswa kelas X SMA Swasta Swadaya Bulu Cina kecamatan hamparan perak .
\end{abstract}

Kata Kunci : Model Inkuiri, Kemampuan Menulis, Teks Anekdot.

\begin{abstract}
The purpose of this research is to determine the effect of the inquiry learning model on the ability to write anecdote texts by class X SMA Swadaya Bulu Cina, Hamparan Perak. Type of research is a quantitative study with a quasi-experimental method. The sample used was 25 students. The research design in this study was a one group pre test-post test design. The instrument used to collect data in this research was a test. The data collection techniques used were observation and documentation. The data analysis technique uses the SPSS computerized technique to be able to draw conclusions Based on the results of data analysis, it can be concluded that the average score of students' writing anecdote text before the application of the inquiry learning model was only 59.76 and after the application of the inquiry learning model was 71.12 . The t-count value is greater than the t-table value, which is 2.25 more than 2.05 , which means that there is an influence of the inquiry learning model on the ability to write anecdotal texts by grade X students of SMA Swadaya Bulu Cina, Kecamatan Hamparan Perak.
\end{abstract}

Keywords: Inquiry Model, Writing Ability, Anecdote Text.

\section{PENDAHULUAN}

Dalam kurikulum 2013 pembelajaran bahasa Indonesia sudah mengunakan pendekatan barbasis teks. Teks merupakan ungkapan pikiran manusia yang lengkap yang didalamnya memiliki situasi dan konteks. Hal ini bertujuan agar siswa tidak hanya sekedar belajar pengetahuan bahasa saja melainkan 
dapat mengembangkan kemampuan menalar siswa dalam bentuk lisan maupun tulisan. Pendekatan berbasis teks lebih menekankan siswa pada kegiatan menulis. Materi pembelajaran Bahasa Indonesia bagi SMA/SMK/MA/MAK di antaranya adalah menulis teks anekdot.

Menurut Tarigan (2008:3) menulis merupakan "salah satu keterampilan berbahasa". Menulis merupakan salah satu keterampilan berbahasa yang merupakan salah satu aspek untuk menuangkan ide dalam bentuk tulisan. Menulis sebagai wujud kemahiran berbahasa mempunyai manfaat yang besar bagi kehidupan manusia, khususnya para siswa. Pada saat menulis, siswa dituntut berpikir untuk menuangkan gagasan secara tertulis berdasarkan pengetahuan yang dimiliki.

Pengajaran menulis teks anekdot diberikan kepada siswa SMA/SMK/MA/MAK sebagai langkah awal pembelajaran menulis di semester pertama bab pertama. Pembelajaran menulis anekdot memberikan kesempatan pada siswa untuk berkarya seluasluasnya dan menambah kosa kata baru yang belum pernah digunakan dalam bahasa umum. Pengajaran Bahasa Indonesia bertujuan agar siswa terampil berbahasa dan mampu berkomunikasi dengan baik secara lisan maupun tulisan (Limbong, 2016:1).

Namun, pada kenyataannya kemampuan menulis anekdot sulit bagi siswa. Bagi banyak siswa, menulis merupakan hal yang dianggap susah dan tidak menyenangkan. Siswa sering merasa kesulitan dalam mengekspresikan pikirannya dalam tulisan. Beberapa alasan siswa berkaitan dengan sulitnya menentukan kata dalam anekdot yang akan mereka tulis, kehabisan ide ketika akan memulai dan sulitnya mencari inspirasi. Sudah tertanam sejak awal pada diri siswa bahwa menulis itu sangat sulit apalagi berkaitan dengan pembelajaran menulis anekdot.

Pada umumnya kemampuan menulis siswa di sekolah-sekolah masih rendah
(Ekowati, 2013:1). Berdasarkan hasil observasi pada siswa kelas X SMA Swasta Swadaya Bulu Cina Kecamatan Hamparan Perak diketahui bahwa pembelajaran menulis anekdot dirasa sangat sulit bagi siswa. Hal ini didasarkan pada hasil perolehan data nilai siswa dalam pembelajaran menulis anekdot. Untuk nilai siswa tersebut dapat dilihat pada lampiran 1.

Nilai yang dicapai siswa dalam pembelajaran menulis anekdot masih belum memenuhi kriteria ketuntasan minimal di SMA Swasta Swadaya Bulu Cina sebesar 70. Jumlah siswa yang tidak mencapai KKM dalam menulis anekdot dalam hal ini mencapai 100\%. Model pembelajaran konvensional dengan metode ceramah dan penugasan adalah model dan metode yang biasa digunakan dalam proses pembelajarannya sehingga siswa cenderung merasa bosan dalam menerima pelajaran.

Hasil observasi awal melalui pengamatan langsung, ditemukan bahwa terdapat siswa yang tidak memiliki keberanian dalam mengungkapkan ide, kurangnya perhatian siswa terhadap pelajaran dan kurangnya motivasi siswa dalam mengikuti proses pembelajaran. Persoalan bidang pendidikan saat ini adalah bagaimana seorang guru menemukan cara yang terbaik agar dapat berkomunikasi secara efektif dengan siswanya dan dapat membuka wawasan berfikir yang beragam dari seluruh siswa.

Setiap materi pelajaran tentu memiliki tingkat kesukaran yang bervariasi. Pada satu sisi ada bahan pelajaran yang tidak memerlukan alat bantu, tetapi di lain pihak ada bahan pelajaran yang sangat memerlukan alat bantu media pengajaran seperi gambar, charta, dan sebagainya. Bahan pelajaran dengan tingkat kesukaran yang tinggi tentu sukar diproses oleh siswa. Apalagi bagi siswa yang kurang menyukai bahan pelajaran yang disampaikan itu. Pastilah siswa akan cepat merasa bosan dan lelah. Mereka hanya akan 
mengkhayal dan berandai-andai saat melihat papan tulis yang dihiasi kapur dan guru yang hanya memberikan ceramah kepada mereka. Hal ini sudah pasti dapat mempengaruhi prestasi belajar siswa. (Sitepu, 2019: 12)

Oleh sebab itu, guru diharapkan lebih kreatif dalam mengatasi permasalahan yang terjadi dalam proses pembelajaran. Salah satunya dengan menggunakan model pembelajaran yang sesuai dengan tingkat perkembangan siswa dan memberikan pembelajaran yang lebih bermakna. Banyak model pembelajaran yang bisa diterapkan guru sesuai dengan tujuan pembelajaran yang ingin dicapai. Salah satu cara yang dapat dilakukan untuk mengatasi permasalahan yang terjadi adalah dengan menerapkan model pembelajaran inkuiri.

Menurut Ekowati (2013:3) "dari sekian banyak model pembelajaran yang dapat diterapkan dalam pembelajaran menulis adalah model inkuiri". Pembelajaran inkuiri dirancang untuk mengajak siswa secara langsung ke dalam proses ilmiah dalam waktu yang relative singkat. Hasil penelitian Schlenker dalam Trianto (2007:136) menunjukan bahwa "latihan inkuiri dapat meningkatkan pemahaman sains, produktif dalam berpikir kreatif, dan siswa menjadi lebih terampil dalam memperoleh dan menganalisis informasi”.

Selain itu, menurut Shoimin (2014:86) model pembelajaran inkuiri memiliki berbagai kelebihan diantaranya, yaitu dapat mengembangkan aspek kognitif, afektif dan psikomotor secara seimbang sehingga pembelajaran dengan strategi ini dianggap lebih bermakna, dapat memberikan ruang kepada siswa untuk belajar sesuai dengan gaya belajar mereka, sesuai dengan perkembangan psikologi belajar modern yang menganggap belajar adalah proses perubahan tingkah laku berkat adanya pengalaman dan dapat melayani kebutuhan siswa yang memiliki kemapuan di atas rata-rata.
Dalam proses pembelajaran dengan menggunakan model pembelajaran inkuiri, guru memotivasi atau mendorong siswa untuk memiliki pengalaman dan melakukan percobaan yang memungkinkan siswa menemukan prinsip-prinsip untuk mereka sendiri.

\section{METODOLOGI PENELITIAN}

Penelitian ini dilaksanakan di SMA Swasta Swadaya Bulu Cina yang beralamat di di jalan Limo Miri, Bulu Cina, Kec. Hamparan Perak, Kab. Deli Serdang Prov. Sumatera Utara.

Populasi dalam penelitian ini adalah seluruh siswa kelas X SMA Swasta Swadaya Bulu Cina sebanyak 25 siswa. Sampel dalam penelitian ini adalah seluruh siswa tersebut. Hal ini didasarkan pada pendapat Arikunto (2008:116) bahwa apabila populasinya kurang dari 100 lebih baik diambil semua hingga penelitiannya merupakan penelitian populasi.

Adapun jenis penelitian ini merupakan penelitian kuantitatif dengan metode quasi eksperimen. Desain penelitian dalam penelitian ini adalah one group pretest-postest design (Syaodih, 2010:208). One group pretest-postest design merupakan bagian dari penelitian eksperimental semu. Pada desain penelitian ini hanya menggunakan satu kelas, yaitu kelas eksperimen. Dalam penelitian ini penulis menggunakan dua variabel yakni : Variabel bebas (X) yaitu model pembelajaran inkuiri, dan Variabel terikat (Y) yaitu kemampuan menulis teks anekdot.

Instrumen yang digunakan untuk mengumpulkan data dalam penelitian ini adalah tes. Menurut Syaodih, (2010:193) "tes adalah serentetan pertanyaan atau latihan serta alat lain yang digunakan untuk mengukur keterampilan pengetahuan intelegensi, kemampuan atau bakat yang dimilki oleh individu atau kelompok". Tes dalam penelitian ini bertujuan untuk mengukur kemampuan 
menulis teks anekdot siswa dengan kriteria/indikator penilaian sebagai berikut.

Teknik pengumpulan data dalam penelitian ini adalah dengan observasi dan dokumentasi. Setelah data terkumpul selanjutnya akan dianalisis menggunakan teknik komputerisasi SPSS 22 untuk dapat melakukan penarikan kesimpulan. Langkahlangkah analisis tersebut juga dapat dilakukan dengan cara sebagai berikut.

1. Mentabulasi nilai hasil pretest dan postest.

2. Melakukan uji normalitas data, sebelum menguji hipotesis, terlebih dahulu peneliti melakukan uji prasyarat analisis data berupa uji nomalitas. Dalam pengujian prasyarat analisis data, peneliti menggunakan teknik komputerisasi pada SPSS versi 22 dengan uji kolmogorof smirnov (Sujarweni, 2019:52). Untuk menguji apakah data berdistribusi normal atau tidak dapat digunkan acuan bahwa jika sig > 0,05 maka data berdistribusi normal dan jika sig $<0,05$ maka sebaliknya.

3. Mencari nilai mean/rata-rata melalui statistik deskriptif, dengan rumus:

$\bar{x}=\frac{\sum x_{i}}{n} \quad$ (Sudjana, 2005:67)

Keterangan : $\bar{x}=$ Nilai rata-rata

$$
\begin{aligned}
& \sum_{x_{i}}=\text { Jumlah skor total } \\
& \mathrm{n}=\text { Jumlah sampel }
\end{aligned}
$$

4. Menguji hipotesis dan menarik kesimpulan menggunakan uji $t$ dengan rumus sebagai berikut.

$$
t=\frac{M d}{\sqrt{\frac{\sum x^{2} d}{N(N-1)}}} \text { (Arikunto, 2013:125) }
$$

Keterangan:

Md : mean dari deviasi (d) antara postest dan pretest.

xd : perbedaan deviasi dendan mean deviasi.

$\mathrm{N}$ : banyaknya subjek.

Kriteria pengambilan keputusannya adalah jika nilai $t_{\text {hitung }}<t_{\text {tabel }}$ maka kesimpulannya adalah terima $\mathrm{H}_{0}$ tolak $\mathrm{H}_{\mathrm{a}}$. Jika nilai $\mathrm{t}_{\text {hitung }} \geq$ $t_{\text {tabel }}$ maka sebaliknya.

\section{HASIL PENELITIAN}

Pada bagian ini akan dijelaskan tentang hasil penelitian, yaitu data sebelum dan sesudah pelaksanaan model pembelajaran inkuiri terhadap materi menulis teks anekdot. Penerapan model pembelajaran inkuiri ini dimaksudkan untuk meningkatan kemampuan menulis teks anekdot siswa kelas X SMA Swasta Swadaya Bulu Cina.

Berdasarkan tujuan penelitian yang telah ditetapkan yaitu untuk mengetahui pengaruh model pembelajaran inkuiri terhadap kemampuan menulis teks anekdot oleh siswa kelas X SMA Swasta Swadaya Bulu Cina Kecamatan Hamparan Perak sebelum dan sesudah mengikuti proses pembelajaran menggunakan model pembelajaran inkuiri. Pada bagian ini akan dipaparkan hasil analisis data pretest dan postest yang terdiri atas uji normalitas, statistik deskriptif, dan uji hipotesis.

\section{Hasil Uji Normalitas}

Tujuan uji normalitas adalah untuk menilai sebaran data pada sebuah kelompok data atau variabel, apakah sebaran data tersebut berdistribusi normal ataukah tidak. Uji normalitas dalam penelitian ini dilakukan terhadap data pretest dan postest yang ditunjukkan pada tabel berikut. 
Tabel 1 Hasil Uji Normalitas Pretest Dan Postest

\begin{tabular}{llrr}
\hline & & Pretest & Postest \\
\hline Normal Parameters & Mean & 59.7600 & 71.1200 \\
& Std. Deviation & 11.68789 & 7.58463 \\
Most Extreme Differences & Absolute & .138 & .122 \\
& Positive & .138 & .122 \\
& Negative & -.120 & -.098 \\
Test Statistic & & .138 & .122 \\
Asymp. Sig. (2-tailed) & & .200 & .200 \\
\hline
\end{tabular}

Sumber : Data diolah dari sumber primer

Berdasarkan tabel di atas, diketahui bahwa nilai asymp sig (2-tailed) atau nilai signifikansi pada data pretest sebesar 0,200 dan nilai signifikansi pada data postest juga sebesar 0,200 . Nilai tersebut menunjukkan bahwa nilai signifikansi kedua data tersebut lebih dari 0,05, sehingga menunjukkan bahwa data hasil pretest dan postest berdistribusi normal.

\section{Statistik Deskriptif}

Statistik deskriptif menunjukkan kumpulan data yang diperoleh akan tersaji

Tabel 2 Statistik Deskriptif Pretest Dan Postest

\begin{tabular}{|c|c|c|c|c|c|}
\hline & $\mathrm{N}$ & Minimum & Maximum & Mean & Std. Deviation \\
\hline Pretest & 25 & 40.00 & 82.00 & 59.7600 & 11.68789 \\
\hline Postest & 25 & 55.00 & 85.00 & 71.1200 & 7.58463 \\
\hline Valid N & 25 & & & & \\
\hline
\end{tabular}

Sumber : Data diolah dari sumber primer

Berdasarkan tabel di atas tampak jelas bahwa jumlah data atau sampel penelitian ini sebanyak 25 data. Pada hasil pretest diketahu nilai minimum, nilai maksimum, nilai rata-rata, dan standar deviasi berturut-turut adalah 40; 82; 59,76; dan 11,68. Pada hasil postest diketahu nilai minimum, nilai maksimum, nilai rata-rata, dan standar deviasi berturut-turut adalah $55 ; 85 ; 71,12$; dan 7,58.

\section{Uji Hipotesis}

Teknik untuk pengujian hipotesis adalah dengan uji-t menggunakan software dengan ringkas dan rapi serta dapat memberikan informasi inti dari kumpulan data yang ada. Informasi yang dapat diperoleh dari statistik deskriptif berupa jumlah data, nilai maksimal, nilai minimal, nilai rata-rata, dan standar deviasi. Statistik deskriptif dalam penelitian ini merupakan pengolahan data hasil pretest dan postest kemampuan menulis teks anekdot siswa yang dituntukkan pada tabel berikut. aplikasi komputer SPSS 22 melalui analisis paired samples test. Pengambilan keputusannya adalah jikla nilai $t_{\text {hitung }}$ lebih besar dari nilai $t_{\text {tabel}}$, maka Ho ditolak dan $\mathrm{Ha}$ diterima, sedangkan jika niali thitung kurang dari nilai $\mathrm{t}_{\text {tabel}}$, maka Ho diterima dan Ha ditolak dengan taraf signifikansi 5\%. Berikut ini tabel 4.2 hasil uji hipotesis.

Tabel 4 Hasil Uji Hipotesis

\begin{tabular}{ccccc}
\hline Data & & & Sig. (2- \\
& $\mathrm{t}$ & df & tailed) \\
\hline
\end{tabular}




\begin{tabular}{lllll}
\hline Pair 1 & $\begin{array}{l}\text { Postest - } \\
\text { Pretest }\end{array}$ & 2.253 & 24 & .000 \\
\hline
\end{tabular}

Sumber : Data diolah dari sumber primer

Berdasarkan tabel di atas diketahui nilai $t_{\text {hitung }}$ adalah 2,25 dan nilai $t_{\text {tabel }}$ untuk jumlah sampel 25 siswa dan taraf titik kritis 5\% maka di ketahui nilai $t_{\text {tabel }}$ sebesar 2,05. Nilai-nilai tersebut menunjukkan bahwa nilai $t_{\text {hitung }}$ lebih besar dari nilai $t_{\text {tabel }}$ yaitu 2,25 lebih besar dari 2,05 yang artinya adalah menolak $\mathrm{H}_{0}$ dan menerima $\mathrm{H}_{\mathrm{a}}$. Oleh karena itu dapat disimpulkan bahwa terdapat pengaruh model pembelajaran inkuiri terhadap kemampuan menulis teks anekdot oleh siswa kelas X SMA Swasta Swadaya Bulu Cina kecamatan hamparan perak.

Penelitian

pengaruh model

pembelajaran inkuiri ditinjau dari kemampuan menulis teks anekdot siswa terdiri dari satu variabel bebas dan satu variabel terikat. Dalam penelitian ini, yang menjadi variabel bebas adalah model pembelajaran inkuiri, sedangkan variabel terikatnya adalah kemampuan menulis teks anekdot. Dalam pelaksanaan penerapan model pembelajaran inkuiri selama penelitian pada pertemuan pertama mulanya aktivitas siswa untuk berfikir dan mendiskusikan hasil pemikirannya dengan teman dan juga memancing keberanian siswa untuk mengemukakan pendapatnya di depan kelas masih sedikit ragu-ragu namum pada pertemuan selanjutnya mereka sudah mulai terbiasa dengan model pembelajaran inkuiri.

Model tersebut menekankan kepada siswa untuk menemukan sendiri pemahamannya sehingga dapat mengembangkan kemampuan menulisnya. Model pembelajaran ini dapat diterapkan untuk membangun peningkatan kemampuan menulis teks anekdot siswa menjadi lebih baik. Hal ini tampak dari peningkatan hasil nilai rata-rata dari 59,76 saat pretest meningkat menjadi 71,12 saat postest. Pembelajaran inkuiri memberikan peluang kepada siswa untuk mengembangkan kemampuan menulis teks anekdot siswa. Dengan berkembangnya kemampuan menulis teks anekdot siswa maka akan menghasilkan kemampuan siswa dalam bidang menulis lainnya.

Berdasarkan uraian di atas dapat disimpulkan bahwa model pembelajaran inkuiri merupakan model pembelajaran yang dapat membuat siswa menjadi aktif dalam proses pembelajaran untuk menemukan pemahamannya sendiri terhadap materi yang sedang dipelajari sehingga dapat mengasah pengetahuan dan kemampuan menulis siswa. Peningkatan kemampuan menulis teks anekdot siswa lebih spesifik ditunjukkan dari hasil perhitungan uji hipotesis dengan rumus $t$ test diketahui nilai $t_{\text {hitung }}$ adalah 2,25 dengan nilai $\mathrm{t}_{\text {tabel }}$ yang diperoleh dari tabel $\mathrm{t}$ test untuk jumlah sampel 25 siswa dan taraf titik kritis 5\% maka di ketahui nilai $t_{\text {tabel }}$ sebesar 2,05, maka diperoleh $t_{\text {hitung }}>t_{\text {tabel }}(2,25>2,05)$ yang artinya terdapat pengaruh model pembelajaran inkuiri terhadap kemampuan menulis teks anekdot oleh siswa kelas X SMA Swasta Swadaya Bulu Cina Kecamatan Hamparan Perak.

Penelitian ini relevan dengan penelitian yang dilakukan oleh Limbong (2016) dengan judul "Pengaruh Model Pembelajaran Inkuiri Terhadap Kemampuan Menulis Teks Ulasan Drama Siswa Kelas XI SMK Negeri 8 Medan Tahun Pembelajaran 2015/2016". Penelitian ini memiliki kesimpulan bahwa model pembelajaran inkuiri berpengaruh secara positif terhadap kemampuan menulis teks ulasan drama siswa kelas XI SMK Negeri 8 Medan Tahun Pembelajaran 2015/2016.

Penelitian yang dilakukan oleh Ginting (2016) dengan judul" Pengaruh Model Pembelajaran Inkuiri Terhadap Kemampuan Menulis Teks Eksplanasi Oleh Siswa Kelas VII SMP Negeri 2 Tigapanah Tahun Pembelajaran 2015/2016”, berkesimpulan kemampuan menulis teks eksplanasi siswa sebelum menggunakan model pembelajaran inkuiri di 
kelas eksperimen masuk ke dalam kategori cukup dengan nilai rata-rata $=65,75$, sedangkan kemampuan menulis teks eksplanasi siswa sesudah menggunakan model pembelajaran inkuiri masuk ke dalam kategori baik dengan nilai rata-rata $=79,42$. Artinya bahwa terdapat pengaruh strategi pembelajaran inkuiri terhadap kemampuan menulis teks eksplanasi siswa kelas VII SMP Negeri 2 Tigapanah Tahun Pembelajaran 2015/2016.

Penelitian lain juga Harahap (2016), yang berjudul "Pengaruh Model Pembelajaran Inkuiri Terhadap Kemampuan Menulis Paragraf Persuasif oleh Siswa Kelas X SMA Negeri 1 Barumun Tahun Pembelajaran 2015/2016", diperoleh kesimpulan bahwa model pembelajaran inkuiri berpengaruh terhadap kemampuan menulis paragraf persuasif siswa.

\section{KESIMPULAN DAN SARAN}

\section{A. Kesimpulan}

Berdasarkan hasil penelitian yang diperoleh, maka dapat disimpulkan beberapa hal, diantaranya yaitu: pertama, rata-rata kemampuan menulis teks anekdot siswa kelas X SMA Swasta Swadaya Bulu Cina sebelum diterapkannya model pembelajaran inkuiri hanya sebesar 59,76. Kedua, rata-rata kemampuan menulis teks anekdot siswa kelas X SMA Swasta Swadaya Bulu Cina setelah diterapkannya model pembelajaran inkuiri sebesar 71,12. Ketiga, peningkatan kemampuan menulis teks anekdot siswa yang lebih spesifik ditunjukkan dari hasil perhitungan uji hipotesis dengan uji t test diketahui $t_{\text {hitung }}>t_{\text {tabel }}(2,25>$ $2,05)$ yang artinya terdapat pengaruh model pembelajaran inkuiri terhadap kemampuan menulis teks anekdot oleh siswa kelas X SMA Swasta Swadaya Bulu Cina kecamatan hamparan perak

\section{B. Saran}

Berdasarkan hasil penelitian, peneliti dapat memberikan beberapa saran sebagai berikut: pertama, siswa harus aktif dalam proses pembelajaran dengan model pembelajaran inkuiri agar dapat meningkatkan kemampuan menulis teks anekdot serta dapat memberikan pengalaman belajar yang baru, lebih bermakna dan menyenangkan. Kedua, sebaiknya guru dapat menerapkan model pembelajaran inkuiri ataupun alternatif model pembelajaran lainnya yang dapat meningkatkan kemampuan menulis siswa.Bagi sekolah, sebaiknya sekolah memiliki kebijakan dalam melaksanakan proses pembelajaran untuk meningkatkan mutu atau kualitas pembelajaran di sekolah, terutama pada bidang bahasa Indonesia. Ketiga, terus berinovasi dalam melakukan proses pembelajaran untuk kedepannya serta terus meningkatkan wawasan dalam bidang penulisan karya ilmiah, dan bagi peneliti selanjutnya dapat dijadikan sebagai bahan referensi maupun sebagai bahan kutipan untuk melakukan penelitian yang relevan dengan penelitian ini.

\section{DAFTAR PUTAKA}

Arikunto, Suharsimi. 2013. Prosedur Penelitian Suatu Pendekatan Praktik. Jakrata: Rineka Cipta.

Ekowati, Sri Wahyuni. 2013. "Keefektifan Model Inkuiri Dalam Pembelajaran Menulis Paragraf Argumentasi SMAN 1 Waylima”. Jurnal J-Simbol Voleme 7 Nomor 2.

Ginting, Emy Novika Sari. 2016. "Pengaruh Model Pembelajaran Inkuiri Terhadap Kemampuan Menulis Teks Eklplanasi Oleh Siswa Kelas VII SMP Negeri 2 Tigapanah Tahun Pembelajaran 2015/2016". Jurnal Sastra Volume 5 Nomor 2.

Harahap, Ummu Atika. 2016. "Pengaruh Model Pembelajaran Inkuiri Terhadap Kemampuan Menulis Paragraf Persuasif oleh Siswa Kelas X SMA Negeri 1 Barumun Tahun Pembelajaran 
2015/2016”. Jurnal Sastra Volume 5 Nomor 2.

Limbong, Sri Gustina. 2016. "Pengaruh Model Pembelajaran Inkuiri Terhadap Kemampuan Menulis Teks Ulasan Drama Siswa Kelas XI Smk Negeri 8 Medan Tahun Pembelajaran 2015/2016". Jurnal Basastra Volume 5 Nomor 1.

Shoimin, Aris. 2014. 68 Model Pembelajaran Inovatif Dalam Kurikulum 2013. Yogyakarta: Ar-Ruzz Media. 2016. 68 Model Pembelajaran Inovatif Dalam Kurikulum 2013. Yogyakarta: Ar-Ruzz Media.

Sudjana. 2005. Metoda Statistika. Bandung: Tarsito.

Sujarweni, Wiratna. 2019. SPSS Untuk Penelitian. Yogyakarta: Pustaka Baru Press.

Syaodih, Nana. 2010. Metode Penelitian Pendidikan. Bandung: Rosdakarya.

Tarigan, Henry Guntur. 2008. Menulis Sebagai Suatu Kemampuan. Bandung :Angkasa.

Sitepu, Dewi Rulia, 2019. Perbandingan Hasil Belajar Siswa Dengan Menggunakan Media Audiovisual Dan Tanpa Media Audiovisual Pada Materi Struktur dan Fungsi Sel Sebagai Unit Terkecil Kehidupan di Kelas XI SMA Swasta Esa
Prakarsa T.A 2018/2019. Jurnal Serunai. Vol. 5 (1), hlm. 11-18

Trianto. 2010. Mendesain Model Pembelajaran Inovatif-Progresif. Jakarta: Kencana. 